\title{
Beyond the Mummy Track? Part-time Rights, Gender, and Career-Family Dilemmas'
}

\section{Anne Grönlund}

Professor, Department of Social Work, Umeå University

IIda Öun ${ }^{2}$

PhD, Department of Sociology, Umeå University

\begin{abstract}
Statutory rights to part-time work are increasingly discussed and institutionalized, but have been little empirically investigated. On the basis of a survey of Swedish parents $(n=1900)$, the article explores the usage and usefulness of the right to work hour reductions in relation to career-family dilemmas. The results show that the gender composition of the workplace affects both mothers' and fathers' likelihood of reducing work hours. Mothers who reduce work hours experience lower work-family conflict but stronger fears of negative career repercussions. For fathers, the implications of work hour reductions vary with the gender composition of the workplace. Meanwhile, the division of housework is related both to the likelihood of reducing work hours and to its implications. The analysis suggests that even when a statutory right to part-time is provided, workplace norms and men's participation in housework are crucial for changing gender patterns.
\end{abstract}

\section{KEYWORDS}

Part-time work / family policy / gender segregation / housework / work-family conflict / career

\section{Introduction}

s European welfare states struggle to raise female labor force participation while sustaining fertility rates, part-time work is put forward as a policy strategy (European Commission 2017). However, while a number of countries have introduced statutes that make it easier for parents to reduce work hours (Hegewisch \& Gornick 2008), neither the usage nor the implications of such rights have been thoroughly investigated (OECD 2010).

Presumably, a statutory right to reduce work hours would enable parents to accommodate care demands without jeopardizing their careers. However, critics argue that policies promoting part-time work can preserve a 1.5 -earner society with remaining gender inequalities (Estévez-Abe 2005; Mandel \& Semyonov 2006).

Sweden provides an excellent case for studying the relevance of part-time policies in the dual-earner society. Swedish parents have a strong right to reduce work hours, established already in the 1970s. Since then, however, women have drastically increased both their work hours and their educational investments - while retaining the main

\footnotetext{
${ }^{1}$ You can find this text and its DOI at https://tidsskrift.dk/njwls/index.

${ }^{2}$ Corresponding author: Ida.oun@umu.se. Both the authors have contributed equally to the article.
} 
responsibility for childcare and housework. In this situation, the right to part-time work could represent a trap as much as a solution to family-career dilemmas.

In this article, we use a recent survey of Swedish parents $(\mathrm{n} \approx 1900)$ to examine, first, how mothers and fathers utilize the right to reduce work hours and, second, how such reductions affect parents' perceptions of work-family conflict and fears about negative career repercussions, respectively. In both cases, we analyze the importance of labor market gender segregation and the division of work in the family. In the first part of the analysis, we use multinomial regressions to explore if the likelihood of reducing work hours reflects spouses' relative resources, their sharing of housework and/or the gender composition of the workplace. In the second part of the analysis, we use ordinary least square (OLS) regressions to explore how work hour reductions are related to the level of work-family conflict and to fears of negative career repercussions of parenthood.

\section{Previous research and our contribution}

In the current European situation, where female labor force participation rates fall behind official goals (Eurostat 2018a) while fertility rates stay below the replacement level (Eurostat 2018b), issues of work-family reconciliation have soared to the top of the policy agenda. To handle these dilemmas, policies such as the right to request part-time work have been put forth as a central part of the EU strategy to reach the 2020 employment target (European Commission 2017).

Meanwhile, however, a substantial body of research has pointed to the drawbacks and risks of part-time work. Part-time work has been associated with lower job quality, less opportunity for training and promotion, and lower wages (Bardasi \& Gornick 2008; Manning \& Petrongolo 2008; Nelen \& de Grip 2009; OECD 2007, 2010; Russo $\&$ Hassink 2008). Moreover, part-time work is offered mainly in female-dominated occupations and industries (Dolado et al. 2002; Petrongolo 2004). Thus, while part-time jobs may enable women to join the labor force and remain there throughout the childrearing years, such arrangements are likely to hamper their skill and career development. On a societal level, then, part-time work could reproduce horizontal and vertical gender segregation and a traditional division of unpaid work in the family (EstévezAbe 2005).

Potentially, these problems could be alleviated through family policy interventions. Statutes enabling parents to reduce work hours while retaining their jobs and work tasks could provide women with a possibility to keep work-family conflict down without ending up in dead-end 'mummy tracks'. Constructed as an absolute right, available across occupations and positions, part-time work could also be an option for fathers. At the same time, however, legislated rights might be at odds with demands and norms in workplaces and families.

Over the past decades, a large number of countries have passed laws introducing rights to part-time work. However, the construction of these rights differs vastly between countries. The statutes can be designed as a right for parents to gradually return to work on a part-time basis after childbirth, as a possibility to use parts of the parental leave to reduce work hours, or as a right for parents of young children to reduce hours without compensation (Hegewisch \& Gornick 2008). In some countries, statutes are targeted specifically to parents, while a few countries offer all employees the right to reduce work 
hours. Finally, part-time can be a strong right or a softer right-to-request, meaning that a reduction of work hours has to be negotiated with the employer (Hegewisch 2009; OECD 2010). Empirical studies show that the introduction of statutory rights to work part-time has resulted in an increase in women's labor force participation (Hegewisch, 2009; OECD 2010). However, the usage and implications of the rights to reduce work hours have been little investigated (OECD 2010). While such statutes can bring women and mothers into the labor market, we do not know if they will hamper or facilitate the transition from a 1.5-earner society to a more gender equal dual-earner society.

In this transition, the Nordic countries play a leading role. Already in the 1980s, female labor force participation rates in these countries were high by international standards. Thirty years later, the Nordic countries are still ahead, with gender gaps in labor force participation varying from $2.9 \%$ to $5.4 \%$ - as compared to $15.3 \%$ for the OECD countries on average (OECD 2017). The same patterns are found for maternal employment. ${ }^{1}$ In sum, women in the Nordic countries have gained a firm foothold in the labor market and combine work and family roles throughout the childrearing years. This 'success story' of female employment is commonly attributed to the Nordic family policy model based on generous parental leave schemes and extensive provision of public day-care ${ }^{2}$ (Korpi 2000).

At the same time, Nordic women have retained the main responsibility for unpaid work in the family (Öun 2013). Although the sharing of parental leaves and housework has become more equal (Duvander \& Lammi-Taskula 2011), fathers' uptake of parental leave days only ranges from around 9\% in Denmark and Finland to 21-30\% in Norway, Sweden, and Iceland (Statistics Denmark 2018) and Nordic mothers still take the lion's share of the unpaid housework (Öun 2013). These differences in family responsibilities translate into gender differences in wages and careers (Boye et al. 2017; Grönlund et al. 2017), as well as in health (e.g., Angelov et al. 2011). Furthermore, labor market gender segregation remains strong (Grönlund et al. 2017).

In light of these persistent inequalities, Nordic family policies are increasingly problemized. Recently, scholars have argued that these policies have brought mothers into the labor market by institutionalizing female work interruptions and part-time work and that, thereby, they have promoted labor market segregation and employer discrimination of women (e.g., Mandel \& Semyonov 2006; cf. Estévez-Abe 2005). From this viewpoint, the Nordic policies would sustain a gendered 1.5-earner society, creating structural barriers for women with career ambitions.

The debates on the Nordic model raise the question of the long-term consequences of statutory part-time rights. It can be argued that once women are well established on the labor market, their aspirations and expectations - as well as their bargaining position in the family - change. In this situation, strategies for work-family reconciliation become more complex than traditional theories assume. Until recently, research on work-family interactions has been heavily dominated by the role strain hypothesis. The basic premise in this hypothesis is that because people have limited time and energy, dual roles in work and family create stressful conflict (Goode 1960 - for the construct of work-family conflict, see below). Thus, there is a strong incentive for individuals to focus on one sphere, for example, the family, and limit their commitment to the other, for example, by working part-time. However, this perspective has been challenged by the role expansion hypothesis. According to this hypothesis, which has received increasing attention in work-family research, dual roles in work and family can enhance performance and 
wellbeing in both spheres (Barnett \& Hyde 2001). Considering both these perspectives, we argue that in a context where both men and women strive to maximize the benefits from dual roles in work and family, parents are confronted with new dilemmas. Here, the relevance and role of policies enabling part-time work is not obvious.

The Swedish context constitutes a good starting point for studying these issues. In 1978, Sweden was the first country to introduce a right for parents to reduce work hours, and in an international perspective, the Swedish policies still stand out as the most comprehensive (Hegewisch \& Gornick 2008). The Swedish Parental Leave Act provides all parents with an unequivocal right to reduce their work hours with up to $25 \%$ (with a corresponding reduction in wages) until the youngest child is 8 years old. Additionally, parental leave compensation - currently available for 480 days $^{3}-$ can be used to reduce work hours up to $75 \%$ until the child is 8 years old. In other words, Swedish parents have a strong right to part-time work - even compared to other Nordic countries (Grönlund et al. 2017).

Sweden also provides a close-up view of the career-family dilemmas facing parents in the dual-earner society. Over the years, Swedish women have further strengthened their commitment to work and career. Women now invest more than men in higher education (Björklund et al. 2010) and are increasingly employed in skilled jobs. The gender gap in normal average work hours has shrunk substantially, from 7.8 hours in 1987 to 3.6 hours a week in 2016 (Statistics Sweden 2017), ${ }^{4}$ and the share of female part-time work has decreased. With the OECD cut-off of 30 hours, the share of Swedish women working full-time rose from 70.2 in 1987 to 82.2 in 2016, while the OECD average decreased from 76.9 to $74.2 \%$ (OECD 2017). In the European Labor Force Survey, where the definition of part-time work is based on self-reports or a 35-hour cut-off, the incidence of female part-time work is higher, reflecting the fact that part-time work in the Nordic countries often implies long hours. Even with this definition, however, female part-time work in Sweden has decreased. The same trend can be observed in Norway and, particularly before the 2000s, in Iceland. In Denmark, the share of women working part-time has remained stable, and in Finland, part-time work has increased from a low level (Appendix Table Ax1 - for a longer time perspective see Wennemo Lanninger \& Sundström 2014).

In the current situation, neither the willingness nor the possibility to reduce work hours is self-evident. Instead, both these factors may be compromised by demands and norms in working life and family.

Due to demands and norms in work, temporary part-time could be problematic in skilled jobs. In skilled jobs, employment contracts are based on considerable employee autonomy and performances are evaluated in terms of results rather than hours worked and recent developments related to new technologies and organizational models have further loosened the regulation of work, leaving individuals responsible for defining and delimiting work (e.g., Allvin \& Aronsson 2003). In this situation, a reduction of work hours may not be accompanied with a corresponding reduction in work load and responsibilities and, in fact, cause work to spill over negatively on private life. Similarly, a reduction of hours may raise fears of negative career implications. Previous research suggests that employees hesitate to make use of workplace policies allowing different forms of flexible scheduling - notably, part-time work - because they fear negative career repercussions. According to Williams et al. (2013), parents risk a 'flexibility stigma' because the implicit contract between the worker and the firm is based on a 
work devotion schema, assuming that employees will minimize time spent on caregiving. On the basis of these insights, it can be argued that a reduction of work hours would be penalized in skilled jobs. Clearly, however, the demands and norms of work are also related to gender stereotypes. Considering the persistent gender segregation in the labor market and the fact that women's need for part-time work is regarded as a main driver behind such segregation (e.g., Estévez-Abe 2005), we would assume that full-time norms and the work devotion schema are particularly salient in male-dominated jobs and workplaces. Using the right to reduce work hours in these workplaces may signal a lack of work commitment and trigger a 'flexibility stigma', particularly for fathers.

Clearly, the reduction of work hours can be expected to reflect demands and norms in the family. Empirically, the relative resources of spouses have been related to the division of unpaid work in the family (Brines 1994; Evertsson \& Nermo 2007), although different theoretical interpretations are offered. For example, Lundberg and Pollack (1996) claim that the relative income of spouses reflects women's bargaining position rather than a rational specialization aimed at maximizing household utility, as argued in human capital theory (Becker 1981/1991). Nevertheless, a substantial gender difference remains in the division of housework and childcare after accounting for human capital and labor market involvement (e.g., Halleröd 2005), pointing to the importance of gendered norms. At the same time, ideals of gender equality and equal sharing of parental responsibilities are more widespread in Sweden than in many other countries (Edlund \& Öun 2016). Thus, in the Swedish context, clashes between traditional norms and modern ideals of gender equality create dilemmas, which are likely to affect parents' deliberations on work hour reductions. After investing in higher education, women may worry that part-time work will push the division of unpaid work in the family in a more traditional direction, with negative implications for their wages and careers. At the same time, fathers' increasing involvement in the household could allow women to engage more fully in their careers, making the right to work hour reductions less relevant.

As mentioned, there is a conspicuous lack of empirical research concerning the usage and implications of a statutory right to work hour reductions. It is notable that even in Sweden, where this right has been in place for decades, research is limited to a few qualitative studies (Grönlund \& Javornik 2014; Larsson 2012) and official statistics do not report on parents' work hour reductions. To further our understanding of these issues, we exploit a recent survey to parents of pre-school children to explore how mothers and fathers in Sweden use the right to reduce work hours and how usage affects work-family conflict on the one hand and fears of negative career consequences on the other hand. The analysis comprises two parts. In the first part, we study how the likelihood for mothers and fathers to reduce work hours is related to the relative resources of the spouses, the division of housework, and the gender composition of the workplace. In the second part, we examine how a reduction of work hours relates to perceptions of work-family conflict as well as to fears of negative career repercussions of parenthood.

The construct of work-family conflict has a dominating standing in survey-based work-family research (Byron 2005; Greenhaus \& Beutell 1985). Work-family conflict captures subjective experiences of work infringing negatively on private life, and although several studies confirm that demands from work - notably, the number of work hours predict a higher level of conflict, we are not aware of any study that has examined the importance of work hour reductions among parents. The examination of respondents' fears of negative career repercussions relate to previous research on the 'flexibility stigma'. 
Most studies on the subject have been carried out in an Anglo-Saxon context where a reduction of work hours has to be negotiated with the employer.

\section{Aim and research questions}

The aim of the analysis is to explore the possibilities and predicaments related to parents' usage of statutory rights to work hour reductions. We address two main questions.

(1) Does the likelihood of reducing work hours reflect spouses' relative resources, their sharing of housework, and/or the gender composition of the workplace?

Hypothesis 1a. Parents - especially mothers - are less likely to reduce work hours if their partner has a higher education and/or longer work hours.

Hypothesis 1b. When fathers take a larger responsibility for housework and childcare mothers are less likely and fathers more likely to reduce work hours.

Hypothesis 1c. Parents - especially fathers - employed at male-dominated workplaces are less likely to reduce work hours than parents at female-dominated workplaces.

(2) Do work hour reductions enable parents to keep work-family conflict down without triggering fears of negative career repercussions? Are the relationships moderated by the skill level of the job and the gender composition of the workplace?

Hypothesis 2a. Parents - especially mothers - who have reduced work hours experience less work-family conflict than parents who remained in full-time work.

Hypothesis $2 \mathrm{~b}$. The association between work hour reductions and work-family conflict is weaker among parents with university education and parents in maledominated workplaces (interaction effects).

Hypothesis 2c. Parents - especially fathers - who have reduced work hours experience more career fears than parents who remained in full-time work.

Hypothesis $2 \mathrm{~d}$. The association between work hour reductions and career fears is stronger among parents with university education and parents in male-dominated workplaces (interaction effects).

\section{Data and method}

The data come from a postal survey conducted in Sweden during the winter 2015-2016. Sampling, distribution, and coding was administered by Statistics Sweden. The sample was a simple random sample drawn from the national register of the total population and comprised 5000 parents whose youngest child was between 3 and 6 years of age at the time of the survey. The motivation for this sampling strategy was to include parents who were eligible for work hour reductions and whose youngest child had not yet started school. The lower age limit of the child was set to exclude families in which one of the partners could still be on full-time parental leave. Due to an initial mistake in the sampling procedure at Statistics Sweden, the sample of 5000 parents had to be drawn 
twice. The first sample erroneously included parents who also had a child who was younger than our target group, and therefore, a second sample was drawn.

The response rate was $35 \%$. However, some respondents from the first sample matched our criteria for inclusion, and calculations made by Statistics Sweden confirmed that their sampling probability was very similar to that of the second sample. It was thus possible to add these respondents to the final sample to increase the statistical power of our analyses. Analysis of attrition rates shows little difference in responses between mothers and fathers. Individuals with only compulsory education (and unclassified education) were underrepresented among the respondents, while those with tertiary education were overrepresented. However, the share of individuals with secondary education did not differ substantially from that of the population. Also, immigrants and children of immigrants were underrepresented among the respondents, as were individuals with very low incomes. On the basis of this information, we conclude that the analyses presented here are likely to capture the situation for parents with secondary and post-secondary education (together representing $75 \%$ of the population) but may not fully reflect the work-family arrangements of groups that are more marginalized on the labor market. In this article, we use a subsample comprising employed mothers and fathers living with a spouse/partner $(\mathrm{n}=1905)$.

In the first part of the analysis, we use multinomial regressions to explore if the likelihood of reducing work hours reflects spouses' relative resources, their sharing of housework, and/or the gender composition of the workplace. The dependent variable is work hour reductions after the birth of the youngest child. The variable is divided into three categories of working time reductions and one category comprising parents who remained in full-time work. The main category of interest is that of parents who utilized the policy option and reduced hours from full-time to part-time, which is compared to the reference category of parents who continued to work full-time without reducing hours. However, we also show results for parents who were already in part-time work at the birth of the child, and for parents who shortened long hours without going below the requirements for full-time work (e.g., by reducing overtime).

In this part of the analysis, we use two sets of independent variables. First, we study the importance of the spouses' relative resources and their sharing of housework. Relative resources can be measured in different way, but economic resources such as income or wages appear to be a more common indicator than education (see, e.g., Aassve et al. 2014). To fruitfully relate relative resources to work hour reductions, however, we need to know the resources of partners before the work hour reduction took place, and unfortunately, the dataset does not include such retrospective information on economic resources. Instead, we use spouses' educational level, which is less time-dependent. Spouses' educational level is a combined measure of the respondent's and partner's education divided into three categories: both/respondent university, partner university, neither respondent nor partner university (reference category). Previous research suggests that education is highly correlated with occupational prestige (Wegener 1992) and we regard university education as a proxy for skilled jobs and use it as a rough measure of relative resources. Presumably, occupational prestige is a better indicator of the job skill level and hence of spouses' relative resources, but the dataset does not include the partner's prestige. However, we perform a sensitivity test where we include the respondents' level of prestige instead of education. The respondent's prestige is based on Treiman's Standard International Occupational Prestige Scale (SIOPS), divided into 
high and low prestige, where high prestige is defined as the 75 th percentile or higher on the scale ( $\geq 60$ in this sample).

The sharing of unpaid work in the household is measured with an additive index of nine common household and child care chores and describes which of the spouses usually does the chore. The index is constructed out of the following question: In your household, who does the following things ...? (a) does the laundry, (b) shops for groceries, (c) does the household cleaning, (d) prepares the meals, (e) leaves/picks up children from childcare, (f) drives children to activities, (g) puts children to bed, (h) plans family activities, (i) takes care of sick children (response categories: always the mother; usually the mother; about equal or both together; usually the father; always the father; is done by a third person). The index ranges from 9 to 45 and higher values indicate that the father does a larger share of the unpaid work (alpha $=0.69$, mean 24.08). Cases where a task is performed by a third person have been included in the category of equal sharing. The partner's work hours are included as a control variable (three categories: 1-34 hours/week, 35-40 hours/week, more than 40 hours/week).

Second, we analyze the importance of the gender composition of the work place. This variable includes three categories: mainly men, gender-mixed, and mainly women (reference category). Obviously, gender segregation is also related to employment sector and occupational choice. To disentangle the gender composition of the workplace from segregation at the occupational/sectoral level, we include employment sector (public/ private) as a control variable. Also, we perform sensitivity analyses including a variable measuring the percentage of women in the occupation, based on register information from Statistics Sweden. Finally, the respondent's level of education (university/no university) is included as a control.

In the second part of the analysis, OLS regressions are used to explore how work hour reductions, particularly changes from full-time to part-time are related to the level of work-family conflict and to fears of negative career repercussions of parenthood. Work-family conflict is an index of four survey questions in which the respondent was asked to assess how often he or she a) keeps worrying about work problems when he/she is not working, b) feels too tired after work to enjoy the things he/she would like to do at home, c) finds that his/her job prevents him/her from giving the time he/she wants to his/her partner or family, and d) finds that his/her partner or family gets fed up with the pressure of his/her job (index range 4-20, higher values indicate higher conflict; Alpha = 0.81 , mean 11.80). This is an established measure of work-family conflict or more precisely, work interference with family (WIF). In previous research, it has been recognized that work-family conflict can take two directions, WIF and family interference with work (FIW). WIF is clearly the most prevalent, and the most commonly studied type of conflict and here, work demands are far more consequential than family demands (e.g., Byron, 2005; Carlson et al., 2000). To measure fears of negative career repercussions, we constructed the index of career fears. This index comprises five survey questions in which the respondents were asked whether they are worried that their parenthood may have negative consequences for their a) salary, b) work environment, c) work tasks, d) possibilities for advancement, and e) job security (index range 5-20, higher values indicate more career fears; Alpha $=0.88$, mean 8.64).

These indexes are used as dependent variables in OLS regressions carried out separately for mothers and fathers. Both these analyses follow the same set-up. The main independent variable is the variable of work hour reductions, which is described above 
but again, the focus of interest lies on the parents reducing hours from full-time to parttime. We first consider the overall effect of work hour reductions, then examine interaction terms between work hour reductions and university education and between work hour reductions and the share of women in the workplace, respectively (see categories above). As controls, we include indicators of job demands and job control. These factors are central to research on work and stress (Karasek \& Theorell 1990; van der Doef \& Maes 1999) but have also been used in research on work-family conflict (see, e.g., Byron 2005; Grönlund \& Öun 2018). Job demands is an index of two survey questions that measure the time pressure and the mental strain inherent in the respondent's job (range $2-10$, higher values indicate higher demands). Job control is an index of four questions capturing the respondent's degree of control over a) which work tasks to perform, b) the way to perform work tasks, c) work pace, and d) important decisions concerning the work place (range 4-20, higher values indicate more control). Finally, to capture demands from the family sphere, we include the measure of the division of unpaid work in the household described above.

To get a clear picture of gendered patterns, we conduct separate regressions for mothers and fathers. However, we also examine and comment on the overall gender gaps.

\section{Results}

To get an overview of work hour reductions in the sample, frequencies are presented in Table 1. As the table summarizes, most mothers and fathers did not change their work hours after their youngest child was born. The majority of the parents continued to work full-time, while a small share was already in a part-time job when the child was born. Still, $40 \%$ of the mothers and almost $25 \%$ of the fathers reduced their work hours in connection to parenthood. Among those reducing hours, most mothers used the policy option of changing from full-time to part-time. Meanwhile, the most common choice among fathers was to shorten long hours. Only about $6 \%$ of the fathers changed from full-time to part-time.

The first research question was whether the likelihood of reducing work hours reflect spouses' relative resources, their sharing of housework, and/or the gender composition at the workplace. Tables 2 and 3 display the results from multinomial regressions where parents reporting different types of working time reduction are compared to parents who remained in full-time work without reducing hours. The analytical focus is on the parents who used the policy option and changed from full-time to part-time work after

Table I Work hour reduction with youngest child. Frequencies

\begin{tabular}{lcc}
\hline & Mothers & Fathers \\
\hline Already part-time & 7.2 & 2.0 \\
\hline Full-time to part-time & 30.1 & 6.1 \\
\hline Shortening long hours & 10.0 & 16.1 \\
\hline Full-time, no reduction & 52.7 & 75.8 \\
\hline $\mathrm{N}$ & 998 & 800 \\
\hline
\end{tabular}


Table 2 Work hour reduction and spouses' relative resources and sharing of housework. Multinomial logistic regression (reference category: full time/ no change). Odds ratios

\begin{tabular}{|c|c|c|c|c|c|c|}
\hline & \multicolumn{2}{|c|}{$\begin{array}{c}\text { Already } \\
\text { part-time }\end{array}$} & \multicolumn{2}{|c|}{$\begin{array}{c}\text { Full-time } \\
\text { to part-time }\end{array}$} & \multicolumn{2}{|c|}{$\begin{array}{l}\text { Shortened } \\
\text { long hours }\end{array}$} \\
\hline & Mothers & Fathers & Mothers & Fathers & Mothers & Fathers \\
\hline \multicolumn{7}{|c|}{ University (Ref: No university) } \\
\hline - Both or respondent only & 0.44 & 1.83 & 0.88 & 3.13 & 1.34 & 1.44 \\
\hline - Partner only & 1.07 & 4.04 & 0.63 & 2.35 & 1.60 & 1.12 \\
\hline \multicolumn{7}{|l|}{$\begin{array}{l}\text { Work hours partner } \\
\text { (Ref: } 35-40 \mathrm{~h} / \mathrm{w} \text { ) }\end{array}$} \\
\hline$-1-34 h / w$ & 3.49 & 2.73 & 3.04 & 1.94 & 0.62 & 0.97 \\
\hline$->40 \mathrm{~h} / \mathrm{w}$ & 1.06 & 1.43 & 1.08 & 0.42 & 1.31 & 1.17 \\
\hline Housework equality & 0.92 & 1.13 & 0.90 & 1.28 & 0.99 & 1.08 \\
\hline \multicolumn{7}{|l|}{ N mothers 915 , fathers 700} \\
\hline \multicolumn{7}{|c|}{ Pseudo R2 \% mothers 6.6, fathers 8.0} \\
\hline
\end{tabular}

Note: Bold coefficients statistically significant on the $5 \%$ level.

Table 3 Work hour reduction and gender composition of workplace. Multinomial logistic regression (reference category: full time/ no change). Odds ratios

\begin{tabular}{|c|c|c|c|c|c|c|}
\hline & \multicolumn{2}{|c|}{$\begin{array}{c}\text { Already } \\
\text { part-time }\end{array}$} & \multicolumn{2}{|c|}{$\begin{array}{l}\text { Full-time } \\
\text { to part-time }\end{array}$} & \multicolumn{2}{|c|}{$\begin{array}{l}\text { Shortened } \\
\text { long hours }\end{array}$} \\
\hline & Mothers & Fathers & Mothers & Fathers & Mothers & Fathers \\
\hline \multicolumn{7}{|l|}{$\begin{array}{l}\text { Gender composition at } \\
\text { workplace (Ref: Majority } \\
\text { women) }\end{array}$} \\
\hline - Majority men & 0.30 & 0.45 & 0.38 & 0.26 & 1.98 & 1.40 \\
\hline - Mixed & 0.26 & 0.50 & 0.66 & 0.41 & 1.37 & 1.18 \\
\hline University (Ref: No university) & 0.41 & 0.83 & 0.94 & 1.80 & 1.05 & 1.70 \\
\hline Public sector (Ref: Private) & 0.81 & 0.92 & 0.81 & 1.18 & 0.67 & 0.97 \\
\hline \multicolumn{7}{|l|}{$\mathrm{N}$ mothers 981 , fathers 792} \\
\hline \multicolumn{7}{|c|}{ Pseudo R2 \% mothers 7.3 , fathers 4.7} \\
\hline
\end{tabular}

Note: Bold coefficients statistically significant on the $5 \%$ level.

parenthood. However, also those parents who remained in a part-time job (without further reducing hours) and those who shortened long hours without going below the requirements for full-time will be briefly discussed.

In Table 2, we examine the importance of relative resources and the sharing of housework of the partners. As summarized in the table, mothers with a university degree are less likely to have had a part-time job before the birth of the youngest child. However, the educational level of the spouses does not predict a reduction from full-time to part-time or a shortening of long hours, neither for mothers nor for fathers. Moreover, 
we find that neither mothers nor fathers reduce their work hours in response to a situation where their partner works long hours, as suggested in the specialization/relative resource perspective. In fact, mothers with a partner working less than 35 hours are more likely to turn to part-time work themselves than those whose partner works 35 hours or more. Thus, hypothesis 1a is not supported. To test another operationalization of resources, we performed further analyses (not displayed) where the respondents' prestige was included instead of education. Noting that information about the partners' prestige is lacking, the overall results of the analysis do not change with this change of indicator.

Finally, we note that men's involvement in unpaid work is significantly related to both mothers' and fathers' probability of reducing work hours after childbirth. Fathers who contribute more to housework and childcare are more likely to change from fulltime to part-time and also more likely to shorten long hours. Meanwhile, mothers are less likely to go from full-time to part-time (or to already be working part-time) if their partner is more involved at home. Thus, Hypothesis $1 \mathrm{~b}$ is fully supported. Clearly, with the cross-sectional data at hand, causal relationships cannot be determined. The results could be interpreted as reflecting a rational specialization in which the person who works fewer hours puts in more time at home; however, considering the gendered division of housework, it is notable that the same patterns apply to both mothers and fathers. Another possibility is that work hour reductions reflect a broader household contract based on gender equality ideals and prioritization of family time. To explore the latter proposition, we conducted further analyses in which the indicator of housework was replaced with a measure capturing the division of parental leave between spouses. The results (available from authors on request) show that in families where the father took a larger share of parental leave, he is more likely to later reduce work hours from full-time to part-time. Moreover, mothers are less likely to turn to part-time work if the father has taken a larger share of parental leave. These findings suggest that in some families, there may be a broader contract comprising both longer parental leaves for fathers and a more equal division of housework and that, in these families, fathers are more likely and mothers less likely to reduce their work hours.

Table 3 displays the results from regressions examining the importance of the gender composition of the workplace. Here, we find that both mothers and fathers are significantly more likely to reduce work hours from full-time to part-time if they are employed at a workplace numerically dominated by women, rather than at a workplace dominated by men or a gender-mixed workplace. This finding stands even after controlling for employment sector and the respondent's educational level, supporting hypothesis $1 \mathrm{c}$ for both mothers and fathers. To disentangle the importance of the workplace from that of occupation and sector, we have carried out further analyses (not shown) including an indicator of the gender composition of the occupation. This analysis shows that the effect of the workplace remains for both mothers and fathers even after introducing gender composition at the occupational level. Interestingly, both the gender composition of the workplace and the occupational gender composition matter for mothers' likelihood to reduce work hours, whereas for fathers, only the workplace indicator is statistically significant.

Next, we turn to the second research question, asking whether work hour reductions enable parents to keep work-family conflict down without triggering fears of negative career repercussions, and if the relationships are moderated by the skill level of the job 
and the gender composition of the workplace. Results from OLS regressions addressing these questions are presented in Tables 4-7.

Regarding work-family conflict, Table 4 model 1a shows that both mothers already in part-time work and those who reduced work hours from full-time to part-time report a lower level of conflict than mothers remaining in full-time work after their youngest child was born. The coefficients are slightly reduced but remain significant after entering the controls in model $1 \mathrm{~b}$. Regarding the control variables, we find that mothers with a university education experience a higher level of conflict than those with lower education and that job demands increase the level of conflict while job control reduces conflict, as indicated by previous research. However, the division of housework and childcare is not related to the mothers' level of work-family conflict. In the following models, we

Table 4 Work-to-family conflict. OLS regressions. Unstandardized b coefficients. Mothers

\begin{tabular}{|c|c|c|c|c|c|c|}
\hline & MIa & MIb & M2a & M2b & M3a & M3b \\
\hline Intercept & I2.45 & 8.18 & 11.42 & 7.81 & 12.56 & 8.08 \\
\hline \multicolumn{7}{|c|}{ Working time reduction (Ref: Full-time) } \\
\hline - Already part-time & -1.25 & -0.83 & 0.08 & 0.31 & -1.46 & -0.88 \\
\hline - Full-time to part-time & -0.58 & -0.45 & -0.15 & -0.05 & -0.56 & -0.37 \\
\hline - Shortened long hours & -0.40 & -0.24 & 0.11 & 0.44 & -0.53 & -0.30 \\
\hline University (Ref: No university) & & 0.59 & 1.20 & 0.99 & & 0.59 \\
\hline \multicolumn{7}{|l|}{$\begin{array}{l}\text { Gender composition at workplace } \\
\text { (Ref: Majority women) }\end{array}$} \\
\hline - Majority men & & & & & 0.09 & 0.25 \\
\hline - Mixed & & & & & -0.43 & -0.07 \\
\hline Job demands & & 0.76 & & 0.76 & & 0.76 \\
\hline Job control & & -0.11 & & -0.11 & & -0.11 \\
\hline Housework equality & & -0.01 & & -0.01 & & 0.01 \\
\hline \multicolumn{7}{|c|}{ Interaction:Working time reduction*University } \\
\hline - Already part-time*University & & & -1.66 & -1.60 & & \\
\hline - Full-time to part-time*University & & & -0.48 & -0.48 & & \\
\hline - Shortened long hours*University & & & -0.61 & -0.80 & & \\
\hline
\end{tabular}

\begin{tabular}{|c|c|c|c|c|c|c|}
\hline \multicolumn{7}{|c|}{$\begin{array}{l}\text { Interaction: Working time reduction*Gender } \\
\text { composition }\end{array}$} \\
\hline - Already part-time*Majority men & & & & & -0.90 & 0.07 \\
\hline - Already part-time*Mixed & & & & & 1.96 & 0.60 \\
\hline - Full-time to part-time*Majority men & & & & & -0.30 & -0.22 \\
\hline - Full-time to part-time*Mixed & & & & & 0.04 & -0.14 \\
\hline - Shortened long hours*Majority men & & & & & 0.55 & 0.65 \\
\hline - Shortened long hours*Mixed & & & & & -0.28 & -0.70 \\
\hline N & 913 & 913 & 913 & 913 & 913 & 913 \\
\hline
\end{tabular}

Note: Bold coefficients statistically significant on the $5 \%$ level. 
Table 5 Work-to-family conflict. OLS regressions. Unstandardized b coefficients. Fathers

\begin{tabular}{|c|c|c|c|c|c|c|}
\hline & MIa & MIb & M2a & M2b & M3a & M3b \\
\hline Intercept & 11.30 & 9.14 & 10.91 & 9.24 & 11.69 & 9.42 \\
\hline \multicolumn{7}{|l|}{ Working time reduction (Ref: Full-time) } \\
\hline - Already part-time & -1.10 & -1.19 & -1.57 & -1.48 & -0.02 & -0.02 \\
\hline - Full-time to part-time & -0.67 & -0.49 & -2.68 & -1.66 & -1.74 & -1.59 \\
\hline - Shortened long hours & 0.53 & 0.53 & -0.04 & 0.31 & -0.61 & -0.41 \\
\hline University (Ref: No university) & & 0.56 & 0.62 & 0.46 & & 0.55 \\
\hline \multicolumn{7}{|l|}{$\begin{array}{l}\text { Gender composition at workplace } \\
\text { (Ref: Majority women) }\end{array}$} \\
\hline - Majority men & & & & & -0.54 & -0.30 \\
\hline - Mixed & & & & & -0.26 & -0.16 \\
\hline Job demands & & 0.71 & & 0.70 & & 0.71 \\
\hline Job control & & -0.09 & & -0.09 & & -0.09 \\
\hline Housework equality & & -0.05 & & -0.05 & & -0.05 \\
\hline \multicolumn{7}{|l|}{$\begin{array}{l}\text { Interaction: Working time } \\
\text { reduction*University }\end{array}$} \\
\hline - Already part-time*University & & & 0.83 & 0.48 & & \\
\hline - Full-time to part-time*University & & & 2.38 & 1.47 & & \\
\hline - Shortened long hours*University & & & 0.69 & 0.34 & & \\
\hline \multicolumn{7}{|l|}{$\begin{array}{l}\text { Interaction: Working time } \\
\text { reduction*Gender composition }\end{array}$} \\
\hline - Already part-time*Majority men & & & & & -0.88 & -1.09 \\
\hline - Already part-time*Mixed & & & & & -2.41 & -2.38 \\
\hline - Full-time to part-time*Majority men & & & & & 2.26 & 1.97 \\
\hline - Full-time to part-time*Mixed & & & & & 0.73 & 1.50 \\
\hline - Shortened long hours*Majority men & & & & & 1.43 & 1.17 \\
\hline - Shortened long hours*Mixed & & & & & 1.00 & 0.85 \\
\hline$N$ & 738 & 738 & 738 & 738 & 738 & 738 \\
\hline
\end{tabular}

Note: Bold coefficients statistically significant on the $5 \%$ level.

consider interaction effects between work hour reductions and the respondent's level of education (models $2 \mathrm{a}$ and $\mathrm{b}$ ) and between work hour reductions and the gender composition of the workplace (models $3 \mathrm{a}$ and $\mathrm{b}$ ). As the table summarizes, these interaction terms are not significant for mothers reducing hours from full-time to part-time.

Turning to Table 5, we note that for fathers, a reduction of work hours is not associated with a significantly lower level of work-family conflict. Moreover, fathers who have shortened long hours report a higher level of conflict, at least after controlling for demands in work and family. For fathers, there are also significant interaction effects. As shown in model $2 \mathrm{a}$, reducing hours from full-time to part-time has radically different effects depending on the father's level of education. Among fathers with a university 
Table 6 Fear of career implications. OLS regressions. Unstandardized b coefficients. Mothers

\begin{tabular}{|c|c|c|c|c|c|c|}
\hline & MIa & MIb & M2a & M2b & M3a & M3b \\
\hline Intercept & 8.91 & 11.65 & 9.01 & 11.44 & 8.80 & 11.42 \\
\hline \multicolumn{7}{|l|}{ Working time reduction (Ref: Full-time) } \\
\hline - Already part-time & -0.34 & -0.50 & 0.47 & 0.44 & -0.35 & -0.41 \\
\hline - Full-time to part-time & 0.57 & 0.35 & 0.26 & 0.11 & 0.68 & 0.52 \\
\hline - Shortened long hours & 0.34 & 0.50 & 1.78 & 1.89 & 0.62 & 0.74 \\
\hline University (Ref: No university) & & -0.14 & -0.18 & 0.05 & & -0.17 \\
\hline \multicolumn{7}{|l|}{$\begin{array}{l}\text { Gender composition at workplace } \\
\text { (Ref: Majority women) }\end{array}$} \\
\hline - Majority men & & & & & 0.90 & 1.09 \\
\hline - Mixed & & & & & -0.25 & 0.13 \\
\hline Job demands & & 0.35 & & 0.35 & & 0.36 \\
\hline Job control & & -0.23 & & -0.24 & & -0.24 \\
\hline Housework equality & & -0.08 & & -0.08 & & -0.08 \\
\hline \multicolumn{7}{|l|}{$\begin{array}{l}\text { Interaction: Working time } \\
\text { reduction*University }\end{array}$} \\
\hline - Already part-time*University & & & -1.25 & -1.35 & & \\
\hline - Full-time to part-time*University & & & 0.37 & 0.31 & & \\
\hline - Shortened long hours*University & & & -1.66 & -1.62 & & \\
\hline \multicolumn{7}{|l|}{$\begin{array}{l}\text { Interaction: Working time } \\
\text { reduction*Gender composition }\end{array}$} \\
\hline - Already part-time*Majority men & & & & & -1.20 & -0.32 \\
\hline - Already part-time*Mixed & & & & & 1.43 & 0.46 \\
\hline - Full-time to part-time*Majority men & & & & & -0.41 & -0.24 \\
\hline - Full-time to part-time*Mixed & & & & & 0.02 & -0.16 \\
\hline - Shortened long hours*Majority men & & & & & -1.02 & -0.90 \\
\hline - Shortened long hours*Mixed & & & & & -0.21 & -0.28 \\
\hline$N$ & 904 & 904 & 904 & 904 & 904 & 904 \\
\hline
\end{tabular}

Note: Bold coefficients statistically significant on the $5 \%$ level.

degree, the reduction of work hours is associated with a higher level of conflict, while for fathers without a degree, the level of conflict is lowered, as compared to the fathers not reducing work hours. The finding suggests that in skilled jobs, the reduction of work hours is not necessarily followed by a corresponding reduction of work demands and the fact that the interaction becomes nonsignificant after entering the controls in model $2 \mathrm{~b}$ appears to support such an interpretation. Significant interaction effects are found also in model 3a, showing that for fathers in workplaces dominated by women, a reduction in hours from full-time to part-time is associated with a lower level of conflict, whereas fathers who have turned to part-time in male-dominated workplaces report a higher level of conflict than those who did not reduce work hours. The interaction may 
Table 7 Fear of career implications. OLS regressions. Unstandardized b coefficients. Fathers

\begin{tabular}{|c|c|c|c|c|c|c|}
\hline & MIa & MIb & M2a & M2b & M3a & M3b \\
\hline Intercept & 7.72 & 9.40 & 7.49 & 9.37 & 7.73 & 9.37 \\
\hline \multicolumn{7}{|l|}{ Working time reduction (Ref: Full-time) } \\
\hline - Already part-time & -0.16 & -0.48 & 0.01 & -0.36 & 2.03 & 1.38 \\
\hline - Full-time to part-time & 1.01 & 0.92 & 2.06 & 2.28 & 0.22 & 0.15 \\
\hline - Shortened long hours & 0.93 & 0.97 & 0.75 & 0.95 & 1.11 & 1.29 \\
\hline University (Ref: No university) & & 0.35 & 0.36 & 0.43 & & 0.34 \\
\hline \multicolumn{7}{|l|}{$\begin{array}{l}\text { Gender composition at workplace } \\
\text { (Ref: Majority women) }\end{array}$} \\
\hline - Majority men & & & & & -0.04 & 0.03 \\
\hline - Mixed & & & & & 0.07 & 0.13 \\
\hline Job demands & & 0.31 & & 0.31 & & 0.30 \\
\hline Job control & & -0.25 & & -0.24 & & -0.24 \\
\hline Housework equality & & -0.01 & & -0.02 & & -0.01 \\
\hline \multicolumn{7}{|l|}{$\begin{array}{l}\text { Interaction: Working time } \\
\text { reduction*University }\end{array}$} \\
\hline - Already part-time*University & & & -0.26 & -0.18 & & \\
\hline - Full-time to part-time*University & & & -1.39 & -1.70 & & \\
\hline - Shortened long hours*University & & & 0.20 & 0.13 & & \\
\hline \multicolumn{7}{|c|}{$\begin{array}{l}\text { Interaction: Working time reduction*Gender } \\
\text { composition }\end{array}$} \\
\hline - Already part-time*Majority men & & & & & -2.84 & -2.54 \\
\hline - Already part-time*Mixed & & & & & -3.07 & -2.32 \\
\hline - Full-time to part-time*Majority men & & & & & 2.22 & 1.98 \\
\hline - Full-time to part-time*Mixed & & & & & 0.16 & 0.51 \\
\hline - Shortened long hours*Majority men & & & & & -0.06 & -0.24 \\
\hline - Shortened long hours*Mixed & & & & & -0.55 & -0.67 \\
\hline$N$ & 736 & 736 & 736 & 736 & 736 & 736 \\
\hline
\end{tabular}

Note: Bold coefficients statistically significant on the $5 \%$ level.

reflect the full-time norm prevailing in male-dominated workplaces, involving difficulties to reduce demands in accordance with the work hour reduction. This interpretation is strengthened by the fact that the coefficient becomes nonsignificant after entering the controls. In sum, these results show that hypothesis $2 \mathrm{a}$ is supported only for mothers, while hypothesis $2 \mathrm{~b}$ is supported only for fathers.

Next, we examine the possibility that work hour reductions would raise parents' fears of negative repercussions on their work and careers. The regression results in Table 6 model 1a show that mothers turning from full-time to part-time work report higher levels of career fears than mothers remaining in full-time work. However, the coefficient is no longer statistically significant after entering the controls in model $1 \mathrm{~b}$ and 
further analysis shows that the change is associated with the housework index. Thus, the higher level of career fears appears to be explained by the fact that mothers who turn to part-time work also take a larger responsibility for unpaid work in the household than mothers remaining in full-time work (see Table 2). The model also shows that, regardless of working time arrangements and work demands, a more equal sharing of housework and childcare is associated with a lower level of career fears. For the other control variables, we find that higher job demands are related to stronger career fears, while job control reduces fears. Models $2 \mathrm{a}$ and $3 \mathrm{a}$ show no significant interaction effects either between work hour reductions and education or between work hour reductions and the gender composition of the workplace.

For fathers, Table 7 model 1a shows that fathers who reduced work hours after their youngest child was born - either by turning to part-time work or by shortening long hours - report stronger career fears than fathers in full-time work who did not reduce hours. The relationships remain significant after entering controls in model $1 \mathrm{~b}$. As for mothers, the interaction terms in model 2 are nonsignificant, thus the relationship between work hour reductions and career fears does not appear to be moderated by education. However, in model $3 \mathrm{a}$, we find a significant interaction term showing that a reduction of work hours from full-time to part-time is associated with heightened levels of career fears for fathers working at a male-dominated workplace, but not for those employed at a female-dominated workplace. In sum, these results show that hypothesis $2 \mathrm{c}$ is supported for both mothers and fathers, while Hypothesis $2 \mathrm{~d}$ is partly supported for fathers.

Finally, we will zoom out and consider the broader meaning of work hour reductions in the context of gender inequalities in paid and unpaid work. Regressions based on the total sample (see Table Ax2 in Appendix) show that mothers on average experience a significantly higher level of work-family conflict than fathers. Also, mothers report stronger fears that parenthood will impact negatively on their work and career. Presumably, these patterns reflect women's larger responsibilities - symbolically and in terms of actual work load - for childcare and housework. The fact that women resort to part-time work, or temporarily reduce hours in connection to parenthood, must be regarded as a way to better cope with this situation; however, as demonstrated in the table, these adaptions did not close the gender gaps.

\section{Discussion}

While entitlements to part-time work are increasingly considered as a policy tool for bringing mothers into the labor market, such policies may institutionalize a 1.5 -earner society with gender inequalities in paid and unpaid work. The thrust of the above analysis was to explore how a right to reduce work hours can alleviate career-family dilemmas in a dual-earner context.

The findings - based on a sample of Swedish parents - show that mothers who reduce work hours from full-time to part-time experience less work-family conflict than mothers remaining in full-time work. However, they also report stronger fears of negative career repercussions. Fathers are much less likely than mothers to utilize the right to work hour reductions, but for those who do, fears of negative career repercussions are heightened. Unlike mothers, however, fathers who turned to part-time work do not 
perceive a lower level of work-family conflict than those who continued working fulltime after their youngest child was born. Arguably, men who adapt work hours may do it not to alleviate their own burdens as much as to distribute burdens more equally within the family. Thus, work hour reductions could be of less relevance for fathers' perceptions of work-family conflict. However, our findings also suggest that, for fathers, demands and norms at the workplace can compromise the benefits of reducing work hours.

Although Swedish family policy provides a strong right to part-time work, we find the value of this statute to be moderated by labor market gender segregation. In our study, both mothers and fathers were more likely to use the right to part-time work if their workplace was numerically dominated by women and less likely if men were in majority. A potential explanation could be that employment contracts in male-dominated jobs and workplaces are inherently based on a work devotion schema, and in this situation, work hour reductions could imply a risk of stigma and wage/career penalties. In line with this reasoning, we find that a reduction of work hours is associated with higher levels of work-family conflict and intensified fears of negative career repercussions for fathers in male-dominated workplaces, as well as for fathers with a university degree, working in more skilled jobs. For women, as a contrast, the work context did not modify the implications of work hour reductions. These findings must be interpreted against the backdrop of the gender beliefs or stereotypes underlying the division of paid and unpaid work (Ridgeway \& Correll 2004). Constructed as providers, fathers are not expected to let care obligations impinge on their jobs, while mothers may face a 'maternal wall' bias (Williams et al. 2013:222) in which their work commitment is questioned by default. By the same token, women are expected to adapt their work to family demands, for example, by reducing hours.

Further supporting this argument, we find that, in comparison to fathers, mothers report more fears that parenthood will have negative consequences for their careers. Previous research of gender differences suggests that these fears are not unwarranted. Despite the Swedish family policies providing parents with tools and services for balancing work and family, studies confirm that gender differences in wages and careers increase in connection to parenthood (e.g., Bygren \& Gähler 2012). However, our study also points to the importance of new ideals of equal sharing of family responsibilities. Supporting and extending previous research on fathers' parental leaves and the division of unpaid work (Boye \& Evertsson forthcoming), we find that both are related to the usage of work hour reductions, for fathers as well as for mothers. The results also show that the sharing of housework crucially affects mothers' fears of negative career repercussions.

Finally, our analysis indicates that the workplace level is of significance even in an encompassing welfare state. Although Swedish family policies are constructed to promote a gender equal sharing of paid and unpaid work, we find that workplace norms related to gender segregation can provide a mechanism by which gendered use of policy rights is sustained. These findings tie in with another Swedish study (Bygren $\&$ Duvander 2006), showing that fathers in male-dominated workplaces use less parental leave than those working in female-dominated workplaces.

The study presented above has several limitations. Due to the cross-sectional design, we cannot make causal inferences and the response rate calls for some caution in the interpretation of the results. In particular, the results may not reflect the situation of 
marginalized groups. Therefore, and considering that in practice, family policy rights and benefits require a stable labor market attachment, the work-family dilemmas of these groups call for more in-depth studies.

With these caveats in mind, we hope to have contributed to and inspired further research. To further examine the gendered implications of statutory rights to part-time work, research from different family policy contexts is important. However, to pinpoint the importance of policies, comparisons within policy 'regimes' - such as the Nordic countries - may also be helpful. Also, our study underlines the importance of exploring the role of workplaces.

In terms of policy implications, our study suggests that policies promoting parttime work should be combined with those directly addressing the sharing of unpaid work in the family, such as individualized parental leave schemes with equal rights for fathers and mothers. As shown above, such measures are likely to affect also the spouses' work-family arrangements including work hour reductions. Still, the right to reduce work hours during the childrearing years remains an important tool for parents to keep work-family conflict down. Previous research indicates that this conflict is comparatively high in the dual-earner societies of the Nordic countries (Grönlund \& Öun 2010) and one reason may be that 'family time' has decreased due to women's longer work hours (Larsson 2012). Thus, in a situation where mothers and fathers strive to combine dual roles in work and family, the issue of limiting work hours remains central.

\section{Acknowledgment}

For financial support, the authors gratefully acknowledge the Swedish Research Council for Health, Working Life and Welfare (FORTE), grant number 2013-0342.

\section{References}

Allvin, M. \& Aronsson, G. (2003). The future of work environment reforms, International Journal of Health Services 33(1): 99-111. doi: http://dx.doi.org/10.2190/1D2L-2HV2OQLL-4PGW.

Angelov, N., Johansson, P., Lindahl, E. \& Lindström, E-A. (2011). Kvinnors och mäns sjukfrånvaro (Women's and men's absence due to illness), IFAU Rapport 2011:2, Uppsala: IFAU.

Aassve, A., Fuochi, G. \& Mencarini, L. (2014). Desperate housework: relative resources, time availability, economic dependency, and gender ideology across Europe, Journal of Family Issues 35(8): 1000-1022. doi: http://dx.doi.org/10.1177/0192513X14522248.

Bardasi, E. \& Gornick, J. (2008). Working for less? Women's part-time wage penalties across countries, Feminist Economics 14(1): 37-32. doi: http://dx.doi.org/10.1080/ 13545700701716649.

Becker, G. (1981/1991). A Treatise on the Family, Cambridge (Mass.) and London: Harvard University Press.

Björklund, A., Fredriksson, P., Gustafsson, J-E. \& Öckert, B. (2010). Den svenska utbildningspolitikens arbetsmarknadseffekter: vad säger forskningen? (Labor market impacts of the Swedish education policy: what does research say?) IFAU rapport 2010:13. Uppsala: IFAU. 
Boye, K. (2014). Hushållsarbetets tid och fördelning (Housework time and distribution). In: Boye, K., and Nermo, M. (eds.) Lönsamt arbete - familjeansvarets fördelning och konsekvenser. (Profitable work - the distribution and consequences of family responsibilities.) SOU 2014:28. Stockholm: Fritzes, 95-129.

Barnett, R. C. \& Hyde, J. S. (2001). Women, men, work, and family: an expansionist theory, American Psychologist 56(10): 781-796. doi: http://dx.doi.org/10.1037/0003-066X.56. 10.781.

Boye, K., Halldén, K. \& Magnusson, M. (2017). Stagnation only on the surface? The implications of skill and family responsibilities for the gender wage gap in Sweden, 1974-2010, British Journal of Sociology 68(4): 595-619. doi: http://dx.doi.org/10.1111/1468-4446.12252.

Boye, K. \& Evertsson, M. (forthcoming). Fathers on call? A study on the sharing of care work between parents in Sweden. Forthcoming in Demographic Research.

Brines, J. (1994). Economic dependency, gender, and the division of labor at home, American Journal of Sociology 100(3): 652-688. doi: http://dx.doi.org/10.1086/230577.

Bygren, M. \& Gähler, M. (2012). Family formation and men's and women's attainment of workplace authority, Social Forces 90(3): 795-816. doi: http://dx.doi.org/10.1093/sf/sor008.

Byron, K. (2005). A meta-analytic review of work-family conflict and its antecedents, Journal of Vocational Behaviour 67(2): 169-198. doi: http://dx.doi.org/10.1016/j.jvb.2004.08.009.

Carlson, D. S., Kacmar, K. M. \& Williams, L. J. (2000). Construction and initial validation of a multidimensional measure of work-family conflict, Journal of Vocational Behaviour 56(2): 249-276. doi: http://dx.doi.org/10.1006/jvbe.1999.1713.

Dolado, J. J., Felgueroso, F. \& Jimeno, J. F. (2002). Recent Trends in Occupational Segregation by Gender: A Look Across the Atlantic. CEPR Discussion Paper No. 3421, London: Center for Economic Policy Research.

Duvander, AZ. \& Lammi-Taskula, J. (2011). Parental leave. In Gislason IV \& Björk Eydal G (eds) Parental Leave Childcare and Gender Equality in the Nordic Countries. TemaNord, Copenhagen: Nordic Council of Ministers.

Edlund, J. \& Öun, I. (2016). Who should work and who should care? Attitudes towards the desirable division of labour between mothers and fathers in five European countries, Acta Sociologica 59(2): 151-169. doi: http://dx.doi.org/10.1177/0001699316631024.

Estévez-Abe, M. (2005). Gender bias in skills and social policies: the varieties of capitalism perspectives on sex segregation, Social Politics 12: 180-215. doi: http://dx.doi. org/10.1093/sp/jxi011.

European Commission (2017). Communication from the Commission to the European Parliament, The Council, the European Economic and Social Committee of the Regions an initiative to support work-life balance for working parents and carers, $\operatorname{COM}(2017)$ 252 final. Available at: http://eur-lex.europa.eu/legal-content/EN/TXT/PDF/?uri=CELEX:52017DC0252\& from=EN.

Eurostat (2018a). Statistics Explained: Employment Statistics. Available at: http://ec.europa.eu/eurostat/statistics-explained/index.php?title=Employment statistics/sv\&oldid=370011 (Accessed June 14, 2018).

Eurostat (2018b). Statistics Explained: Fertility Statistics. Available at: http://ec.europa.eu/ eurostat/statistics-explained/index.php/Fertility statistics (Accessed June 14, 2018).

Evertsson, M. \& Nermo, M. (2007). Changing resources and the division of housework: a longitudinal study of Swedish couples, European Sociological Review 23(4): 455-470. doi: http://dx.doi.org/10.1093/esr/jem018.

Goode, W. J. (1960). A theory of role strain, American Sociological Review 25(4): 483-496. doi: http://dx.doi.org/10.2307/2092933.

Greenhaus, J. H. \& Beutell, N. J. (1985). Sources of conflict between work and family roles, Academy of Management Review 10(1): 76-88. doi: http://dx.doi.org/10.5465/ AMR.1985.4277352. 
Grönlund, A. \& Öun, I. (2010). Rethinking work-family conflict: dual-earner policies, role conflict and role expansion in Western Europe, Journal of European Social Policy 20(3): 179-195. doi: http://dx.doi.org/10.1177/0958928710364431.

Grönlund, A. \& Öun, I. (2018). In search of family-friendly careers? Professional strategies, work conditions and gender differences in work-family conflict, Community, Work \& Family 21(1): 87-105. doi: http://dx.doi.org/10.1080/13668803.2017.1375460.

Grönlund, A., Halldén, K. \& Magnusson, C. (2017). A Scandinavian success story?: women's labour market outcomes in Denmark, Finland, Norway and Sweden, Acta Sociologica 60(2): 97-119. doi: http://dx.doi.org/10.1177/0001699316660595.

Grönlund, A. \& Javornik, J. (2014). Great expectations. Dual-earner policies and the management of work-family conflict: the examples of Sweden and Slovenia, Families, Relationships and Societies 3(1): 51-65. doi: http://dx.doi.org/10.1332/204674313X13796044783891.

Halleröd, B. (2005). Sharing of housework and money among Swedish couples: do they behave rationally?, European Sociological Review 21(3): 273-288. doi: http://dx.doi. org/10.1093/esr/jci017.

Hegewisch, A. (2009). Flexible working policies: a comparable review. Available at: http:// www.equalityhumanrights.com/uploaded files/research/16 flexibleworking.pdf.

Hegewisch, A. \& Gornick, J. C. (2008). Statutory routes to workplace flexibility in crossnational perspective (IWPR Report No. B258). Available at: http://www.lisproject.org/ publications/parentwork/flex-work-report.pdf.

Karasek, R. A. \& Theorell, T. (1990). Healthy Work. Stress, Productivity and the Reconstruction of Working Life, New York: Basic Books.

Korpi, W. (2000). Faces of inequality: gender, class and patterns of inequalities in different types of welfare states, Social Politics 7(2): 127-191. doi: http://dx.doi.org/10.1093/ $\mathrm{sp} / 7.2 .127$.

Larsson, J. (2012). Studier i tidsmässig välfärd - med fokus på tidsstrategier och tidspolitik för småbarnsfamiljer. (Studies in temporal welfare - focusing on time strategies and time policies for families with small children.) Göteborg Studies in Sociology No. 49. Doctoral Dissertation at the Department of Sociology, University of Gothenburg.

Lundberg, S. \& Pollack, R. A. (1996). Bargaining and distribution in marriage, The Journal of Economic Perspectives 10(4): 139-158.

Mandel, H. \& Semyonov, M. (2006). A welfare state paradox: state interventions and women's employment opportunities in 22 countries, American Journal of Sociology 111: 1910-1949. doi: http://dx.doi.org/10.1086/499912.

Manning, A. \& Petrongolo, B. (2008). The part-time pay penalty for women in Britain, The Economic Journal 118(526): F28-F51. doi: http://dx.doi.org/10.1111/j.1468-0297. 2007.02115.x.

Nelen, A. \& de Grip, A. (2009). Why do part-time workers invest less in human capital than full-timers?, Labour 23(s1), 61-83. doi: http://dx.doi.org/10.1111/j.1467-9914.2008. 00439.x.

OECD (2007). Babies and Bosses. Reconciling Work and Family Life. A Synthesis of Findings for OECD Countries, Paris: OECD.

OECD (2010). OECD Employment Outlook. Moving Beyond the Jobs Crisis, Paris: OECD.

OECD (2017). OECD Employment Database. Labor Force Statistics. Available at: http:// stats.oecd.org/Index.aspx?DataSetCode=STLABOUR (Accessed April 21, 2017).

Öun, I. (2013). Is it fair to share? Perceptions of fairness in the division of housework among couples in 22 countries, Social Justice Research 26(4): 400-421. doi: http://dx.doi. org/10.1007/s11211-013-0195-x.

Petrongolo, B. (2004). Gender segregation in employment contracts, Journal of the European Economic Association 2(2-3): 331-345. doi: http://dx.doi.org/10.1162/154247604 323068032. 
Ridgeway, C. L. \& Correll, S. (2004). Unpacking the gender system: a theoretical perspective on gender beliefs and social relations, Gender and Society 18(4): 510-531. doi: http:// dx.doi.org/10.1177/0891243204265269.

Russo, G. \& Hassink, W. (2008). The part-time wage gap: a career perspective, De Economist 156(2): 145-174. doi: http://dx.doi.org/10.1007/s10645-008-9087-0.

Statistics Denmark (2018). Nordic statistics on gender equality. Available at: http://norden. statbank.dk/ (Accessed June 14, 2018).

Statistics Sweden (2017). Arbetskraftsundersökningarna (AKU). (Labour force surveys.) Available at: https://www.scb.se/en/finding-statistics/statistics-by-subject-area/labourmarket/labour-force-surveys/labour-force-surveys-lfs/ (Accessed December 2017).

van der Doef, M. \& Maes, S. (1999). The job demand-control(-support) model and psychological wellbeing: a review of 20 years of empirical research, Work and Stress 13(2): 87-114. doi: http://dx.doi.org/10.1080/026783799296084.

Wegener, B. (1992). Concepts and measurement of prestige, Annual Review of Sociology 18: 253-280. doi: http://dx.doi.org/10.1146/annurev.so.18.080192.001345.

Wennemo Lanninger, A. \& Sundström, M. (2014). Part-time work in the Nordic region: Parttime work, gender and economic distribution in the Nordic countries. TemaNord 2014: 503. Available at: http://norden.diva-portal.org/smash/get/diva2:707663/FULLTEXT01. pdf.

Williams, J. C., Blair-Loy, M. \& Berdahl, J. L. (2013). Cultural schemas, social class, and the flexibility stigma, Journal of Social Issues 69(2): 209-234. doi: http://dx.doi.org/10.1111/ josi.12012.

\section{Notes}

1 Employment levels of mothers with pre-school children are considerably higher in the Nordic countries than in the OECD on average (Grönlund et al. 2017). However, for mothers with children below the age of three, employment is lower in Finland than in the other Nordic countries, due to the importance of cash-for-care schemes (see note below).

2 It should be noted that although the Nordic countries are commonly regarded as one family policy model, varying mixes of parental leave entitlements, cash-for-care schemes, and child care services provide parents in the five countries with different possibilities and constraints. In particular, Finland stands out with a strong emphasis on cash-for-care schemes (see Grönlund et al. 2017 and the note above).

3 In 2017, Swedish parental leave compensation comprised 390 days compensated at $80 \%$ of income and 90 days at a flat-rate. The days can be shared freely between the parents except that 3 months are reserved for the father and the mother, respectively.

4 The statistics refer to employed individuals 16-64 years. The narrowing gender gap in weekly work hours is due mainly to an increase in women's working time but also to a decrease in men's average work week. 


\section{Appendix}

Table Ax- I Part-time among women and men (\%)

\begin{tabular}{lcccccc}
\hline & \multicolumn{2}{c}{ Women } & & \multicolumn{3}{c}{ Men } \\
\cline { 2 - 3 } \cline { 5 - 6 } & $\mathbf{2 0 0 7}$ & $\mathbf{2 0 1 7}$ & & $\mathbf{2 0 0 7}$ & $\mathbf{2 0 1 7}$ \\
\hline EU-28 & 28.9 & 29.4 & & 4.7 & 6.6 \\
EU-15 & 35.0 & 35.5 & & 5.0 & 7.7 \\
\hline Finland & 13.5 & 16.7 & & 4.2 & 6.4 \\
Denmark & 27.7 & 26.8 & & 6.3 & 9.2 \\
Iceland & 31.6 & 30.0 & & 4.6 & 7.0 \\
Norway & 37.4 & 30.1 & & 8.3 & 11.0 \\
Sweden & 36.6 & 30.9 & & 7.0 & 10.0 \\
\hline
\end{tabular}

Note: 25-49 years. Based on EU labour force survey.

Source: Eurostat

Table Ax-2 Work-to-family conflict and fear of career implications. OLS regressions. Unstandardized b coefficients

\begin{tabular}{|c|c|c|c|c|c|c|}
\hline & \multicolumn{3}{|c|}{ Work-to-family conflict } & \multicolumn{3}{|c|}{ Career fears } \\
\hline & MI & M2 & M3 & MI & M2 & M3 \\
\hline Intercept & 11.32 & 11.36 & 8.14 & 7.93 & 7.79 & 9.93 \\
\hline Woman (Ref: Man) & 0.83 & 1.02 & 0.48 & 1.16 & 1.05 & 0.71 \\
\hline \multicolumn{7}{|c|}{ Working time reduction (Ref Full-time) } \\
\hline - Already part-time & & -1.18 & -0.89 & & -0.26 & -0.32 \\
\hline - Full-time to part-time & & -0.54 & -0.45 & & 0.69 & 0.60 \\
\hline - Shortened long hours & & 0.12 & 0.15 & & 0.67 & 0.75 \\
\hline University (Ref: No university) & & & 0.58 & & & 0.19 \\
\hline \multicolumn{7}{|c|}{$\begin{array}{l}\text { Gender composition at workplace } \\
\text { (Ref: Majority women) }\end{array}$} \\
\hline - Majority men & & & 0.12 & & & 0.42 \\
\hline - Mixed & & & -0.05 & & & 0.14 \\
\hline Job demands & & & 0.74 & & & 0.33 \\
\hline Job control & & & -0.10 & & & -0.25 \\
\hline Housework equality & & & -0.02 & & & -0.05 \\
\hline $\mathrm{N}$ & $165 \mid$ & $165 \mid$ & $165 \mid$ & 1640 & 1640 & 1640 \\
\hline
\end{tabular}

Note: Bold coefficients statistically significant on the $5 \%$ level. 